\title{
PENGARUH MODEL PEMBELAJARAN KOOPERATIF TIPE THINK PAIR SHARE TERHADAP HASIL BELAJAR MATEMATIKA SISWA KELAS VIII SMP NEGERI 1 PASARWAJO
}

\author{
Muthmainnah $^{1)}$, Suhar ${ }^{2)}$, Hafiludin Sampardja ${ }^{3)}$ \\ 1) Alumni Jurusan Pendidikan Matematika, ${ }^{2,3)}$ Dosen Jurusan Pendidikan \\ Matematika FKIP Universitas Halu Oleo Email: \\ Sittimuthmainnah98@gmail.com;Suhar_fkipmat@gmail.com; \\ hafiludin79@yahoo.com
}

\begin{abstract}
Abstrak
Penelitian ini merupakan penelitian eksperimen semu dengan rancangan posttest only control design. Populasi dalam penelitian ini adalah seluruh siswa kelas VIII SMP Negeri 1 Pasarwajo yang terdiri dari 8 kelas paralel berjumlah 221 siswa. Penentuan sampel dilakukan dengan teknik purposive sampling. Sampel penelitian ini terdiri dari 48 siswa, yang terbagi atas dua kelompok belajar, yaitu kelas VIII B sebagai kelas eksperimen berjumlah 24 siswa dan kelas VIII E sebagai kelas kontrol berjumlah 24 siswa.. Hasil penelitian menunjukkan bahwa: (1) persentase keberhasilan pengelolaan pembelajaran oleh guru pada tujuh pertemuan berturut-turut adalah 99\%,95\%,98\%,99\%,98\%,95\% dan 94\%; (2) rata-rata hasil belajar matematika siswa yang diajar dengan model pembelajaran kooperatif tipe Think Pair Share adalah 56,66; (3) rata-rata hasil belajar matematika siswa yang diajar dengan model pembelajaran langsung adalah 35,05 ; (4) Terdapat pengaruh yang signifikan penggunaan model pembelajaran kooperatif tipe Think Pair Share terhadap hasil belajar matematika.
\end{abstract}

Kata Kunci: model TPS, hasil belajar matematika, think pair share

\section{THE INFLUENCE OF COOPERATIVE LEARNING MODELS TYPES THINK PAIR SHARE ON MATHEMATICS LEARNING OUTCOMES OF CLASS VIII STUDENTS OF SMP NEGERI 1 PASARWAJO}

\begin{abstract}
This research is a quasy-experimental with a posttest only control design. The population in this research are all off the class VIII students of SMP Negeri 1 Pasarwajo consisting of 8 parallel classes totaling 221 students. Determination of samples is done by purposive sampling technique. The research sample consisted of 48 students, which were divided into two study groups, namely class VIII B as an experimental class totaling 24 students and class VIII E as a control class which amounts to 24 students. The research results show that: (1) the percentage of successful management of learning by teachers at seven consecutive meetings are 99\%, 95\%, 98\%, 99\%, 98\%, 95\% and 94\%; (2) the average of the students' mathematics learning outcomes taught by the cooperative learning models types Think Pair Share is 60,41; (3) The average of the students' mathematics learning outcomes taught by direct learning model is 38,85 ; (4) There is a significant influence on the use of the cooperative learning models types Think Pair Share on the students' mathematics learning outcomes.
\end{abstract}

Keywords: models TPS, mathematics learning outcomes, think pair share 


\section{Pendahuluan}

Belajar pada umumnya dilakukan oleh seseorang untuk mendapatkan pengetahuan dan pengalaman baru yang berdampak pada perubahan tingkah laku seseorang, sehingga dari pengetahuan dan pengalaman yang ia dapatkan akan menambah keterampilan, sikap, kebiasaan dan pemahaman tentang hal yang dipelajarinya. Belajar adalah proses melihat, mengamati, memahami sesuatu yang dipelajari sehingga dapat mengubah tingkah laku seseorang atau individu melalui berbagai pengalaman yang ditempuhnya (Suprihatiningrum, 2013: 14). Dalam proses belajar mengajar di sekolah, belajar dapat dipandang sebagai hasil, di mana guru melihat bentuk terakhir dari berbagai pengalaman interaksi edukatif yang diperhatikan adalah menampaknya sifat dan tanda-tanda tingkah laku yang dipelajari. Melihat pada kenyataan dapat dikatakan bahwa melalui peristiwa belajar manusia memperoleh tingkah laku yang baru (Daryanto, 2013: 66-67).

Keberhasilan pencapaian tujuan pendidikan sangat bergantung pada keberhasilan proses belajar siswa di sekolah dan lingkungan sekitarnya. Sudjana menyatakan belajar adalah suatu proses yang ditandai dengan adanya perubahan pada diri seseorang, perubahan sebagai hasil proses belajar dapat ditunjukkan dalam berbagai bentuk seperti perubahan pengetahuan, pemahaman, sikap dan tingkah laku, keterampilan, kecakapan, kebiasaan, serta perubahan aspek-aspek yang ada pada individu yang belajar (Jihad dan Haris, 2013: 2). Berdasarkan beberapa pendapat di atas, dapat disimpulkan bahwa belajar adalah suatu proses aktif yang dilakukan oleh seseorang untuk membangun pengetahuan baru yang diperoleh melalui hasil pemikiran dan interaksi dengan lingkungannya.

Pasal 1 butir 20 UU N0. 20 Tahun 2003 tentang sisdiknas, pembelajaran adalah proses interaksi peserta didik dengan pendidik dan sumber belajar pada suatu lingkungan belajar. Ada terkandung lima komponen pembelajaran yaitu: interaksi, peserta didik, pendidik, sumber belajar, dan lingkungan belajar (Hamzah dan Muhlisrarini, 2014: 42).

Pembelajaran merupakan proses utama yang diselenggarakan dalam kehidupan di sekolah sehingga antara guru yang mengajar dan anak didik yang belajar dituntut profit tertentu. Ini berarti guru dan anak didik harus memenuhi persyaratan, baik dalam pengetahuan, kemampuan sikap dan nilai, serta sifat-sifat pribadi agar pembelajaran dapat terlaksanakan dengan efisien dan efektif (Suprihatiningrum, 2013: 75-76).

Pembelajaran adalah upaya dari guru atau dosen untuk siswa/mahasiswa dalam bentuk kegiatan memilih, menetapkan dan mengembangkan metode dan strategi yang optimal untuk mencapai hasil belajar yang diinginkan. Ada proses interaksi peserta didik dengan pendidik dan sumber belajar pada suatu lingkungan belajar, didalam pembelajaran yang efektif. Dengan ciri-ciri adanya inisiasi, fasilitasi, peningkatan proses belajar peserta didik, interaksi yang diprogramkan antara peserta didik dengan lingkungan dan adanya komponen yang saling berkaitan (Hamzah dan Muhlisrarini, 2014: 58).

Berdasarkan beberapa pendapat di atas, dapat disimpulkan bahwa proses pembelajaran merupakan kegiatan inti dalam pendidikan. Segala sesuatu yang telah diprogramkan akan dilaksanakan dalam proses pembelajaran. Pembelajaran adalah suatu kegiatan yang bernilai edukatif yang dilakukan oleh guru dengan menggunakan metode tertentu yang dapat memberikan hasil optimal terhadap hasil belajar siswa.

Salah satu mata pelajaran yang ada di sekolah adalah matematika. Matematika merupakan salah satu bidang studi yang menduduki peran penting dalam dunia pendidikan, hal ini dapat dilihat dari waktu jam pelajaran sekolah lebih banyak dibandingkan pelajaran lain. Pada umumnya, matematika sering dianggap sebagai mata pelajaran yang sulit dipahami. Disamping itu matematika juga berfungsi untuk mengembangkan kemampuan berkomunikasi dengan menggunakan bilangan dan simbol-simbol serta ketajaman penalaran yang dapat membantu memperjelas dan menyelesaikan permasalahan.

Pembelajaran matematika pada umumnya dipandang sebagai mata pelajaran yang sulit dan kurang diminati. Seharusnya siswa menyadari bahwa kemampuan berpikir logis, kritis, cermat, efisien dan efektif menjadi ciri pembelajaran matematika yang sangat dibutuhkan untuk menghadapi zaman yang semakin maju. Dalam proses pembelajaran matematika, guru memegang peranan yang sangat penting untuk menentukan keberhasilan belajar siswa dalam belajar matematika. Salah 
satu upaya mengembangkan pendidikan adalah keterampilan guru dalam memilih model pembelajaran yang sesuai dengan tujuan pembelajaran, kondisi siswa dan kondisi tempat belajar. Wena (2010: 2) menyatakan bahwa "penggunaan model pembelajaran dalam kegiatan sangat perlu karena untuk mempermudah proses pembelajaran sehingga dapat mencapai hasil yang optimal. Tanpa model yang jelas, proses pembelajaran tidak akan terarah sehingga tujuan pembelajaran yang telah ditetapkan sulit tercapai secara optimal, dengan kata lain pembelajaran tidak dapat berlangsung secara efektif dan efisien".

Model pembelajaran yang kurang tepat akan mempengaruhi proses pembelajaran siswa dalam kelas dan juga hasil belajar siswa. Hal ini juga menjadi masalah yang dihadapi di SMP Negeri 1 Pasarwajo. Berdasarkan hasil wawancara peneliti dengan guru matematika, hasil belajar matematika siswa kelas VIII SMP Negeri 1 Pasarwajo masih tergolong rendah, dilihat dari nilai rata-rata hasil ulangan harian matematika siswa pada hanya 58,6 dengan $65,62 \%$ siswa belum mencapai Kriteria Ketuntasan Minimal (KKM) yang ditetapkan di sekolah tersebut yakni 62. Model pembelajaran yang biasa digunakan oleh guru dalam proses pembelajaran di kelas adalah model pembelajaran langsung dimana guru sebagai pusat utama dalam kelas. Hal ini menyebabkan tingkat perhatian siswa terhadap pelajaran matematika menjadi kurang antusias, terlalu monoton, cenderung tidak aktif, pemusatan pemikiran yang kurang serta rendahnya respon umpan balik siswa terhadap pertanyaan dan penjelasan guru.

Salah satu model yang tepat digunakan untuk memecahkan masalah tersebut adalah penerapan model pembelajaran kooperatif tipe Think Pair Share. Model pembelajaran Think Pair Share adalah strategi diskusi kooperatif yang dikembangkan oleh Frank Lymnan dan koleganya dari Universitas Maryland pada tahun 1981. TPS mampu mengubah asusmsi bahwa metode resitasi dan diskusi perlu diselenggarakan dalam setting kelompok kelas secara keseluruhan. Think Pair Share memberikan kepada siswa waktu untuk berpikir dan merespons serta saling bantu satu sama lain (Shoimin, 2014: 209).

Trianto (2007: 61) menyatakan bahwa pembelajaran kooperatif tipe Think Pair Share dapat melatih dan mengembangkan kemampuan berpikir serta aktivitas siswa yang lain sehingga siswa mampu menggabungkan dan membandingkan pola pikir mereka sendiri dengan pola pikir siswa yang lain. Model pembelajaran ini dapat merangsang kemampuan berpikir tingkat tinggi karena di sini potensi yang dimiliki siswa benar-benar digali semaksimal mungkin. Selain itu kecakapan strategi mereka juga diuji, apa yang akan siswa lakukan terhadap masalah yang dia dapatkan tergantung pada pemikiran mereka sehingga diharapkan siswa dapat berpikir secara optimal. Menurut Arends (Trianto, 2007: 61) menyatakan bahwa Think Pair Share merupakan suatu cara yang efektif untuk membuat variasi suasana pola diskusi kelas. Think Pair Share dimaksudkan sebagai alternatif terhadap metode tradisional yang diterapkan di kelas, seperti ceramah dan tanya jawab satu arah. Selain itu, keunggulan dari Model pembelajaran kooperatif tipe Think Pair Share memiliki prosedur yang secara eksplisit memberi siswa waktu untuk berpikir, menjawab, saling membantu satu sama lain sehingga diharapkan siswa mampu bekerja sama, saling membutuhkan, dan saling bergantung pada kelompok kecil secara kooperatif (Shoimin, 2014: 209).

Menurut Shoimin (2014: 209-210), keterampilan sosial dalam proses pembelajaran TPS antara lain:

a. Keterampilan sosial siswa dalam berkomunikasi meliputi dua aspek.

1. Aspek Bertanya

Aspek bertanya meliputi keterampilan sosial siswa dalam hal bertanya kepada teman dalam satu kelompoknya ketika ada materi yang kurang dimengerti serta bertanya pada diskusi kelas.

2. Aspek menyampaikan ide atau pendapat Meliputi keterampilan siswa menyampaikan pendapat saat diskusi kelompok serta berpendapat (memberikan tanggapan atau sanggahan) saat kelompok lain presentasi.

b. Keterampilan sosial aspek bekerja sama Keterampilan sosial siswa pada aspek yang bekerja sama meliputi keterampilan sosial siswa dalam hal bekerja sama dengan teman dalam satu kelompok untuk menyelesaikan soala yang diberikan oleh guru.

c. Keterampilan sosial aspek menjadi pendengar yang baik

Keterampilan sosial siswa pada aspek menjadi pendengar yang baik, yaitu 
keterampilan dalam hal mendengarkan guru, teman dari kelompok lain saat sedang presentasi maupun saat teman dari kelompok lain berpendapat.

d. Komponen pembelajaran kooperatif tipe TPS

Pembelajaran Think Pair Share mempunyai beberapa komponen.
1. Think (Berpikir)

2. Pair (Berpasangan)

3. Share (berbagi)

Langkah-langkah pembelajaran yang digunakan dalam penelitian ini adalah dari pendapat Kurniasih dan Berlin (2017: 62-63). Sintaks model pembelajaran kooperatif tipe Think Pair Share dapat dilihat pada tabel 1.

Tabel 1

Sintaks Model Pembelajaran Think Pair Share

\begin{tabular}{|l|l|}
\hline \multicolumn{1}{|c|}{$\begin{array}{c}\text { Sintaks Model } \\
\text { Pembelajaran }\end{array}$} & \multicolumn{1}{c|}{ Kegiatan Pembelajaran } \\
\hline $\begin{array}{l}\text { Tahap 1: Thinking } \\
\text { (Berpikir) }\end{array}$ & $\begin{array}{l}\text { Langkah awalnya guru mengajukan suatu pertanyaan atau masalah } \\
\text { yang dikaitkan dengan pelajaran, dan meminta siswa menggunakan } \\
\text { waktu beberapa menit untuk berpikir sendiri jawaban atau masalah }\end{array}$ \\
\hline $\begin{array}{l}\text { Tahap 2: } \\
\text { Pairing } \\
\text { (Berpasangan) }\end{array}$ & $\begin{array}{l}\text { Dan setelah itu, guru meminta siswa untuk berpasangan dan } \\
\text { mendiskusikan apa yang telah mereka peroleh. Interaksi selama } \\
\text { waktu yang disediakan dapat menyatukan jawaban jika suatu } \\
\text { pertanyaan diajukan menyatukan gagasan apabila suatu masalah } \\
\text { khusus identifikasi. Secara normal guru member waktu tidak lebih } \\
\text { dari 4 atau 5 menit untuk berpasangan. }\end{array}$ \\
\hline $\begin{array}{l}\text { Tahap 3: } \\
\text { Sharing (Berbagi) }\end{array}$ & $\begin{array}{l}\text { Langkah ini adalah langkah akhir, dimana guru meminta pasangan- } \\
\text { pasangan untuk berbagi dengan keseluruhan kelas yang telah } \\
\text { mereka bicarakan. Hal ini efektif untuk berkeliling ruangan dari } \\
\text { pasangan ke pasangan dan melanjutkan sampai sekitar sebagian } \\
\text { pasangan mendapat kesempatan untuk melaporkan. }\end{array}$ \\
\hline
\end{tabular}

Kelebihan Model Pembelajaran Think Pair Share

Menurut Kurniasih dan Berlin (2017: 58-60), kelebihan model kooperatif tipe Think Pair Share sebagai berikut:

1. Model ini dengan sendirinya memberikan kesempatan kepada siswa untuk berpikir, menjawab, dan saling membantu satu sama lain.

2. Dapat meningkatkan partisipasi siswa dalam proses pembelajaran.

3. Lebih banyak kesempatan untuk kontribusi masing-masing anggota kelompok.

4. Antara sesama siswa dapat belajar dari siswa lain serta saling menyampaikan idenya untuk didiskusikan sebelum disampaikan di depan kelas.

5. Dapat memperbaiki rasa percaya diri dan semua siswa diberi kesempatan untuk berpartisipasi dalam kelas.

6. Siswa dapat mengembangkan keterampilan berpikir dan menjawab dalam komunikasi antara satu dengan yang lain, serta bekerja saling membantu dalam kelompok kecil.

7. Keaktifan siswa akan meningkat, karena kelompok yang dibentuk tidak gemuk, dan masing-masing siswa dapat dengan leluasa mengeluarkan pendapat mereka.

8. Proses pembelajaran akan dinamis, karena konsep pembelajaran ini juga menuntuk siswa untuk aktif mencari permasalahan dan menemukan jawabannya.

9. Dengan pembelajaran TPS dapat diminimalisir peran sentral guru sebab semua siswa akan terlibat dengan permasalahan yang diberikan oleh guru.

10. Hasil belajar lebih mendalam, karena model pembelajaran TPS siswa dapat diidentifikasi secara bertahap materi yang diberikan, sehingga pada akhir pembelajaran hasil yang diperoleh siswa dapat lebih optimal.

\section{Metode}

Penelitian ini dilaksanakan di SMP Negeri 1 Pasarwajo. Waktu pelaksanaan penelitian pada tanggal 15 Januari 2019 sampai tanggal 13 Februari 2019, semester genap Tahun Ajaran 2018/2019 di kelas VIII SMP Negeri 1 Pasarwajo pada pokok bahasan Lingkaran. Jenis penelitian yang digunakan dalam penelitian ini adalah penelitian eksperimen semu (Quasy 
experiment), karena tidak sepenuhnya dapat mengontrol variabel-variabel luar yang mempengaruhi pelaksanaan eksperimen ini. Populasi dalam penelitian ini adalah seluruh siswa kelas VIII SMP Negeri 1 Pasarwajo Tahun Ajaran 2018/2019 yang tersebar dalam kelas 8 kelas.

Tabel 2

Nilai rata-rata hasil ulangan harian.

\begin{tabular}{|c|c|c|c|c|}
\hline No. & Kelas & $\begin{array}{c}\text { Jumlah } \\
\text { siswa }\end{array}$ & $\begin{array}{l}\text { Nilai rata-rata } \\
\text { ulangan harian }\end{array}$ & Varians \\
\hline 1. & $\mathrm{VIII}_{\mathrm{A}}$ & 30 & 59.75 & 417,057 \\
\hline 2. & $\mathrm{VIII}_{\mathrm{B}}$ & 24 & 59.5 & 182,161 \\
\hline 3. & VIII $_{C}$ & 29 & 57.5 & 505,739 \\
\hline 4. & $\mathrm{VIII}_{\mathrm{D}}$ & 28 & 56.5 & 380,11 \\
\hline 5. & $\mathrm{VIII}_{\mathrm{E}}$ & 24 & 60 & 237,562 \\
\hline 6. & $\mathrm{VIII}_{\mathrm{F}}$ & 29 & 55 & 603,357 \\
\hline 7. & $\mathrm{VIII}_{\mathrm{G}}$ & 28 & 58 & 436,929 \\
\hline 8. & $\mathrm{VIII}_{\mathrm{H}}$ & 29 & 62.5 & 223,016 \\
\hline \multicolumn{3}{|c|}{ Rata-rata } & 58.6 & \\
\hline
\end{tabular}

Penentuan sampel dalam penelitian ini dilakukan dengan menggunakan teknik purposive sampling yaitu dengan memperhatikan ciri-ciri antara lain: siswa yang diampu oleh guru yang sama, kelas dengan jumlah siswa genap dan kelas dengan nilai ratarata dan variansi yang relatif sama. Berdasarkan kriteria tersebut diperoleh kelas VIII $_{\mathrm{B}}$ dan kelas $\mathrm{VIII}_{\mathrm{E}}$ sebagai sampel penelitian. Selanjutnya, penentuan kelas eksperimen dan kelas kontrol dilakukan secara acak sederhana. Sehingga diperoleh kelas $\mathrm{VIII}_{\mathrm{B}}$ sebagai kelas eksperimen berjumlah 24 orang dan kelas $\mathrm{VIII}_{\mathrm{E}}$ sebagai kelas kontrol yang berjumlah 24 orang.
Variabel dalam penelitian ini terdiri atas dua, yaitu: Variabel bebas dalam penelitian ini adalah perlakuan berupa pembelajaran matematika dengan menggunakan model pembelajaran kooperatif tipe Think Pair Share $(\mathrm{X})$. Variabel terikat dalam penelitian ini adalah hasil belajar matematika siswa yang diajar dengan model pembelajaran kooperatif tipe Think Pair Share (Y).

Model desain yang digunakan dalam penelitian ini adalah model Posttest Only Control Design, dimana dua kelas sampel diberikan perlakuan yang berbeda. Adapun desain yang digunakan digambarkan sebagai berikut:

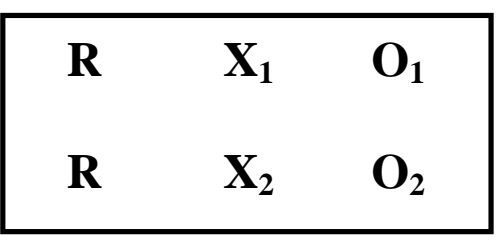

(Sugiyono 2016: 114)

Keterangan:

$\mathrm{R}$ = masing-masing kelas eksperimen dan kelas kontrol dipilih secara Random $(\mathrm{R})$

$\mathrm{X}_{1}=$ Perlakuan pada kelas eksperimen berupa penerapan model Think Pair Share.

$\mathrm{X}_{2}=$ Perlakuan pada kelas kontrol berupa penerapan model pembelajaran langsung.

$\mathrm{O}_{1}=$ Hasil Posttest siswa pada kelas eksperimen dengan pembelajaran menggunakan model Think Pair Share.

$\mathrm{O}_{2}=$ Hasil Posttest siswa pada kelas kontrol dengan menggunakan pembelajaran langsung.

Instrumen penelitian adalah suatu alat yang digunakan untuk mengukur fenomena alam maupun sosial yang diamati (Sugiyono, 2016: 148). Dalam hal ini peneliti akan menggunakan dua instrument yaitu lembar observasi dan tes hasil belajar matematika siswa. Lembar observasi digunakan sebagai lembar pengamatan untuk mengukur aktivitas belajar siswa dan partisipasi guru selama proses pembelajaran. Lembar observasi bertujuan untuk melihat ketercapaian rencana tindakan yang menggambarkan aktivitas guru maupun siswa selama proses pembelajaran berlangsung dengan menggunakan model pembelajaran kooperatif tipe Think Pair Share. Lembar observasi dibuat oleh peneliti dengan mengacu pada Rencana 
Pelaksanaan Pembelajaran (RPP) sesuai sintaks model pembelajaran kooperatif tipe Think Pair Share. Format yang digunakan dalam lembar observasi ialah aktivitas sistematis yang berbentuk isian untuk mengetahui tindakan selama terlaksananya model pembelajaran kooperatif tipe Think Pair Share.

Instrumen ini digunakan untuk mengetahui hasil belajar siswa yang diajar

$$
\mathrm{r}_{\mathrm{XY}}=\frac{N \Sigma X Y-(\Sigma X)(\Sigma Y)}{\sqrt{\left\{N\left(\Sigma X^{2}\right)-(\Sigma X)^{2}\right\}\left\{N\left(\Sigma Y^{2}\right)-(Y)^{2}\right\}}}
$$

(Arikunto, 2015: 87) dengan menggunakan model pembelajaran kooperatif tipe Think Pair Share dan model pembelajaran langsung. Dalam penelitian ini peneliti membuat instrumen tes berupa soal bentuk uraian. Tes diberikan saat Posttest kepada siswa berupa soal tertulis.

Uji validitas instrumen posttest digunakan rumus korelasi Product-Moment sebagai berikut:
Keterangan:

$\mathrm{r}_{\mathrm{XY}}=$ koefisien korelasi antara variable $\mathrm{X}$ dan variabel Y

$\mathrm{X}=$ skor item

$\mathrm{Y}=$ skor total

$\mathrm{N}=$ jumlah responden

Kriteri pengujian:

a. Jika $r_{\mathrm{xy}} \geq \mathrm{r}_{\text {tabel }}$ dengan $\alpha=0,05$ maka item tersebut valid,

b. Jika $r_{\mathrm{xy}}<\mathrm{r}_{\text {tabel }}$ dengan $\alpha=0,05$ maka item tersebut tidak valid.

Hasil analisis validitas instrument posttest hasil belajar matematika disajikan pada tabel 3.

Tabel 3

Hasil analisis validitas posttest hasil belajar matematika

\begin{tabular}{|c|c|c|c|}
\hline $\begin{array}{c}\text { Nomor } \\
\text { Soal }\end{array}$ & $\mathbf{r}_{\text {hitung }}$ & $\mathbf{r}_{\text {tabel }}$ & Keterangan \\
\hline 1 & 0,452 & 0,4132 & Valid \\
\hline 2 & 0,488 & 0,4132 & Valid \\
\hline 3 & 0,596 & 0,4132 & Valid \\
\hline 4 & 0,791 & 0,4132 & Valid \\
\hline 5 & 0,651 & 0,4132 & Valid \\
\hline
\end{tabular}

Berdasarkan tabel 3, pada butir soal nomor 1 diperoleh nilai $r_{\text {hitung }}=0,452 \geq$ $r_{\text {tabel }}=0,4132$ sehingga butir soal tersebut valid. Dan seterusnya sampai pada butir soal nomor 5 dapat dilihat pada tabel 3.5 di atas semua butir soal yang diuji coba valid. Dalam hal ini semua soal dapat mengukur hasil belajar matematika siswa kelas VIII SMP Negeri 1 Pasarwajo.

Untuk mengetahui reliabilitas tes uraian digunakan rumus Alpha Cronbach yaitu: $r_{i i}=\frac{k}{k-1}\left\{1-\frac{\Sigma s_{i}^{2}}{S_{t}^{2}}\right\}$

(Supardi, 2017: 156)

Penilaian kecukupan koefisien reliabilitas tes dapat diacuh dari pendapat Aiken (1988) bahwa jika tes akan digunakan untuk menentukan signifikansi perbedaan rerata skor dua kelompok siswa maka koefisien reliabilitas sebesar 0,65 dianggap memuaskan (Ahiri \& Anwar, 2011: 264). Oleh karena itu, tes yang digunakan dalam penelitian ini adalah tes dengan nilai reliabilitas minimal pada kategori sedang. Hasil analisis reliabilitas instrumen posttest hasil belajar matematika disajikan pada tabel 4.

Tabel 4

Hasil analisis Reliabilitas Instrumen

\begin{tabular}{|l|l|}
\hline $\begin{array}{l}\text { Koefisien } \\
\text { Reliabilitas }\end{array}$ & $\begin{array}{l}\text { Interpretasi } \\
\text { Korelasi }\end{array}$ \\
\hline $\mathbf{0 , 7 2 7}$ & Tinggi \\
\hline
\end{tabular}

Berdasarkan Tabel 4. diperoleh koefisien reliabilitasnya sebesar 0,727 yang dapat diinterpretasikan dalam kategori tinggi. Hal ini berarti bahwa tes ini cukup diandalkan untuk mengukur hasil belajar matematika siswa.

Teknik pengumpulan data dalam penelitian ini adalah dengan menggunakan metode tes dan metode observasi. Metode observasi adalah salah satu cara pengumpulan data dengan pengamatan langsung dan pencatatan secara sistematis terhadap obyek yang akan diteliti. Observasi dilakukan oleh peneliti dengan cara pengamatan dan pencatatan mengenai pelaksanaan pembelajaran di kelas. Sedangkan metode tes digunakan untuk mengetahui hasil belajar siswa yang dilakukan setelah proses pembelajaran telah selesai, baik 
kelas yang diajar dengan menggunakan model pembelajaran kooperatif tipe Think Pair Share (kelas eksperimen) maupun dengan menggunakan model pembelajaran langsung (kelas kontrol). Nilai dari tes tersebut yang akan dijadikan data dalam penelitian ini.

Teknik analisis data dalam penelitian ini menggunakan analisis statistik deskriptif

$$
\mathrm{t}=\frac{\bar{X}_{1}-\bar{X}_{2}}{\sqrt{\frac{\left(n_{1}-1\right) S_{1}^{2}+\left(n_{2}-1\right) S_{2}^{2}}{n_{1}+n_{2}-2}\left(\frac{1}{n_{1}}+\frac{1}{n_{2}}\right)}}
$$

Dengan kriteria pengambilan keputusan Terima $\mathrm{H}_{0}$ jika $\mathrm{t}<\mathrm{t}_{1-\alpha}$ (tabel) , dimana $\mathrm{t}_{1-\alpha}$ diperoleh dari meliputi: nilai rata-rata, median, modus, standar deviasi, varians, skewness, nilai minimum dan nilai maksimum dan analasis statistik inferensial yaitu uji t dengan terlebih dahulu dilakukan uji syarat normalitas dan uji homogenitas. Rumus uji $\mathrm{t}$ yang digunakan adalah uji $\mathrm{t}$ sampel independent.

\section{Hasil}

daftar distribusi t dengan $\mathrm{dk}=\left(\mathrm{n}_{1}+\mathrm{n}_{2}-2\right)$. Untuk harga-harga t lainnya $\mathrm{H}_{0}$ ditolak.

Hasil observasi terhadap pelaksanaan pembelajaran matematika dengan menggunakan model pembelajaran kooperatif tipe Think Pair

Share pada materi lingkaran dapat dilihat pada tabel 5

Tabel 5

Deskripsi Keberhasilan Pengelolaan Pembelajaran oleh Guru Pada Kelas Eksperimen

\begin{tabular}{|c|c|c|c|}
\hline Pertemuan & $\begin{array}{c}\text { Skor Total } \\
\text { Maksimum }\end{array}$ & Skor Perolehan & Persentase \\
\hline Pertama & 100 & 99 & $99 \%$ \\
\hline Kedua & 100 & 95 & $95 \%$ \\
\hline Ketiga & 100 & 98 & $98 \%$ \\
\hline Keempat & 100 & 99 & $99 \%$ \\
\hline Kelima & 100 & 98 & $98 \%$ \\
\hline Keenam & 100 & 95 & $95 \%$ \\
\hline Ketujuh & 100 & 94 & $94 \%$ \\
\hline
\end{tabular}

Berdasarkan tabel 5. persentase keberhasilan pengelolaan pembelajaran pada pertemuan pertama yakni $99 \%$. Pada pertemuan ini guru telah berhasil melaksanakan tahap-tahap pembelajaran kecuali pada bagian membimbing siswa selama mengerjakan soal dalam LKPD yang hanya mendapatkan skor 3 dengan persentase aktivitas 50\% $<x \leq 75 \%$.

Persentase keberhasilan pengelolaan pembelajaran pada pertemuan kedua yakni $95 \%$. Mengalami penurunan dibanding pertemuan pertama dimana terdapat tahap-tahap pembelajaran yang tidak terlaksana, seperti menjelaskan langkah-langkah pembelajaran dan guru tidak memberikan kesempatan kepada kelompok lain yang mempunyai jawaban yang berbeda dari kelompok penyaji untuk menyampaikan hasil diskusinya karena keterbatasan waktu.
Pertemuan ketiga, keempat dan kelima persentase pengelolaan pembelajaran mengalami peningkatan yakni sebesar 98\%, 99\% dan $98 \%$. Guru telah mulai terbiasa melaksanakan hampir semua tahap pembelajaran. Pada pertemuan ketiga, skor keterlaksanaan tahap pembelajaran guru membimbing siswa membuat kesimpulan tentang materi yang telah dipelajari dan guru membimbing siswa melakukan refleksi terhadap pembelajaran sebesar 3 dengan persentase aktivitas guru sebesar 3 dengan persentase aktivitas yang dilakukan guru sebesar 50\% $<x$ $\leq 75 \%$.

Pertemuan keempat tahap pembelajaran yang tidak terlaksana adalah menjelaskan langkah-langkah pembelajaran. Tahap tersebut mendapatkan skor 3 dengan persentase aktivitas yang dilakukan guru sebesar $50 \%<x \leq 75 \%$. Sedangkan pada pertemuan 
kelima, tahap pembelajaran yang tidak terlaksana adalah mengarahkan siswa mendiskusikan jawaban yang diperoleh dengan pasangannya dan membimbing siswa untuk menyiapkan laporan hasil diskusinya secara rapi, rinci dan sistematis. Tahap pembelajaran tersebut mendapatkan skor 3 dengan persentase aktivitas yang dilakukan oleh guru sebesar $50 \%$ $<x \leq 75 \%$.

Persentase pengelolaan pembelajaran pada pertemuan keenam dan ketujuh kembali mengalami penurunan yakni sebesar $95 \%$ dan 94\%. Pada pertemuan keenam, tahap pembelajaran dimana guru mendorong siswa agar secara aktif terlibat dalam diskusi tidak terlaksana dengan baik, tahap pembelajaran tersebut hanya mendapat skor 3 dengan persentase aktivitas pembelajaran sebesar $50 \%<$ $x \leq 75 \%$. Tahap pembelajaran lain yang tidak terlaksana adalah memberikan tugas kepada siswa. Guru terburu-buru untuk menutup pembelajaran sehingga lupa untuk memberikan tugas kepada siswa. Tahap pembelajaran tersebut mendapatkan skor 0 yang berarti tidak ada aktivitas yang dilakukan oleh guru.

Pertemuan ketujuh tahap pembelajaran yang tidak dilakukan oleh guru adalah membimbing siswa membuat kesimpulan tentang materi yang telah dipelajari dan membimbing siswa melakukan refleksi terhadap pembelajaran. Kedua tahapan tersebut mendapat skor 3 dengan aktivitas yang dilakukan guru sebesar $50 \%<x \leq 75 \%$. Selain itu, tahap pembelajaran dimana guru memberikan tugas kepada siswa juga tidak terlaksana dengan skor 0 yang berarti tidak ada aktivitas yang dilakukan oleh guru.

Hasil Pengamatan aktivitas siswa pada kelas eksperimen selama pembelajaran dapat dilihat pada Tabel 6.

Tabel 6

Deskripsi Keaktifan Siswa Kelas Eksperimen

\begin{tabular}{|c|c|c|c|}
\hline Pertemuan & $\begin{array}{c}\text { Skor Total } \\
\text { Maksimum }\end{array}$ & Skor Perolehan & Persentase \\
\hline Pertama & 100 & 97 & $97 \%$ \\
\hline Kedua & 100 & 97 & $97 \%$ \\
\hline Ketiga & 100 & 96 & $96 \%$ \\
\hline Keempat & 100 & 97 & $97 \%$ \\
\hline Kelima & 100 & 95 & $95 \%$ \\
\hline Keenam & 100 & 100 & $100 \%$ \\
\hline Ketujuh & 100 & 98 & $98 \%$ \\
\hline
\end{tabular}

Berdasarkan hasil observasi aktivitas siswa dalam pembelajaran matematika menggunakan model pembelajaran kooperatif tipe Think Pair Share pada materi lingkaran, pada pertemuan pertama dan kedua keterlaksanaan dari seluruh aspek aktivitas siswa yang diamati adalah sebesar $97 \%$. Siswa dapat langsung menyesuaiakan diri dengan model pembelajaran yang diterapkan. Namun masih ada beberapa tahap dimana siswa tidak melakukan aktivitas pembelajaran. Pada pertemuan pertama, tahap dimana siswa mempersiapkan buku pelajaran yang diperlukan dalam proses pembelajaran mendapat skor 3 yang berarti banyaknya siswa yang melakukan aktivitas sebesar $50 \%<x \leq 75 \%$. Hal ini disebabkan karena ada siswa yang tidak membawa buku pelajarannya. Selain itu pada tahapan dimana siswa berani mengemukakan pendapat dan menerima pendapat siswa lain terlihat bahwa banyaknya siswa yang melakukan aktivitas tersebut hanya sebesar 50\% $<x \leq$ $75 \%$. Hal ini disebabkan karena siswa masih dalam tahap penyesuaian untuk berani mengemukakan pendapat di depan temantemannya.

Aktivitas siswa dalam pembelajaran pada pertemuan kedua yang tidak terlaksana adalah pada tahap dimana siswa mempelajari materi yang ada pada buku siswa, siswa menggali informasi dari buku pelajaran dan mengolah informasi yang diperoleh dari buku pelajaran. Ketiga aktivitas tersebut mendapat skor 3 yang berarti bahwa banyaknya siswa yang melakukan aktivitas pembelajaran sebesar $50 \%$ $<x \leq 75 \%$.

Pertemuan ketiga, keempat dan kelima, keterlaksanaan aktivitas siswa dalam pembelajaran di kelas berturut-turut sebesar 96\%, 97\% dan 95\%. Seperti pada pertemuan 
sebelumnya, pada pertemuan ketiga aktivitas pembelajaran yang tidak terlaksana adalah mempersiapkan buku pelajaran yang diperlukan dalam proses pembelajaran, saling bekerja sama, menggali informasi dari buku pelajaran dan mengolah informasi dari buku pelajaran. Ketiga tahap tersebut hanya memperoleh skor 3 yang berarti banyaknya siswa yang melakukan aktivitas hanya sebesar $50 \%<x \leq 75 \%$.

Keterlaksanaan aktivitas siswa dalam pembelajaran pada pertemuan keempat masih terdapat beberapa tahapan aktivitas siswa yang tidak terlaksana yakni memperhatikan saat pemberian materi oleh guru, bertanya kepada guru tentang materi yang kurang jelas dan bertanya kepada teman/guru tentang hal-hal yang kurang jelas. Ketiga tahap tersebut memperoleh skor 3 dimana banyaknya siswa yang melakukan aktivitas sebesar 50\% $<x$ $\leq 75 \%$. Hal ini disebabkan karena siswa sulit untuk memusatkan pikiran pada penjelaskan guru sehingga siswa merasa tidak tertarik terhadap materi yang disampaikan oleh guru. Pemusatan pemikiran yang kurang tersebut dapat diatasi dengan memberikan refleksi sejenak kepada siswa untuk mengumpulkan konsentrasinya dan kembali fokus pada materi yang disampaikan oleh guru.

Pertemuan kelima, keterlaksanaan aktivitas siswa dalam pembelajaran di kelas masih lebih rendah dibandingkan dengan pertemuan keempat. Tahapan aktivitas siswa yang tidak terlaksana adalah memperhatikan saat pemberian materi oleh guru, bertanya kepada guru tentang materi yang kurang jelas, menggali informasi dari buku pelajaran, mengolah informasi yang diperoleh dari buku pelajaran serta bertanya kepada teman/guru tentang hal-hal yang kurang jelas. Kelima aktivitas siswa tersebut mendapatkan skor 3 karena banyaknya siswa yang melakukan aktivitas sebesar 50\% < $x \leq 75 \%$.

Keterlaksanaan aktivitas siswa dalam pembelajaran di kelas pada 2 pertemuan terakhir mengalami peningkatan. Persentase aktivitas siswa pada pertemuan keenam sebesar $100 \%$. Artinya seluruh aktivitas siswa dalam pembelajaran sudah terlaksana dengan baik. Sedangkan pada pertemuan ketujuh, persentase keterlaksanaan aktivitas siswa dalam pembelajaran sebesar 98\%. Pada tahapan aktivitas siswa berani mengemukakan pendapat dan berani menerima pendapat hanya mendapatkan skor 3 sebab banyaknya siswa yang melakukan aktivitas tersebut hanya sebanyak $50 \%<x \leq 75 \%$, dimana $x$ adalah banyaknya siswa.

Berdasarkan hasil analisis deskriptif nilai posttest hasil belajar matematika siswa diperoleh data hasil belajar matematika yang disajikan pada tabel 7 .

Tabel 7

Deskripsi Hasil Belajar Matematika

\begin{tabular}{|l|r|r|}
\hline \multicolumn{1}{|c|}{$\begin{array}{c}\text { Statistik } \\
\text { Deskriptif }\end{array}$} & $\begin{array}{c}\text { Kelas } \\
\text { Eksperimen }\end{array}$ & $\begin{array}{c}\text { Kelas } \\
\text { Kontrol }\end{array}$ \\
\hline Jumlah sampel & 24 & 24 \\
\hline Mean & 60,41 & 38,85 \\
\hline Median & 60 & 29,37 \\
\hline Modus & 26,25 & 20 \\
\hline Std. Deviation & 24 & 24,04 \\
\hline Variance & 576,042 & 577,978 \\
\hline Skewness & 0,015 & 0,803 \\
\hline Minimum & 26,25 & 5 \\
\hline Maximum & 95 & 96,25 \\
\hline
\end{tabular}

Berdasarkan tabel 7 terlihat bahwa pada kelas eksperimen dengan jumlah sampel 24 orang, nilai terendah yang diperoleh siswa adalah 26,25 dan nilai tertinggi adalah 95 . Sedangkan nilai terendah dan tertinggi yang diperoleh siswa pada kelas kontrol dengan jumlah sampel 24 orang berturut-turut adalah 5 dan 96,25. Nilai rata-rata siswa pada kelas eksperimen sebesar 60,41, sedangkan nilai ratarata kelas kontrol sebesar 38,85, median atau nilai tengah pada kelas eksperimen sebesar 60 , sedangkan median pada kelas kontrol sebesar 29,37, Modus atau nilai yang sering muncul pada kelas eksperimen sebesar 26,25, sedangkan modus pada kelas kontrol sebesar 20. Nilai ini menunjukkan bahwa data posttest hasil belajar matematika siswa kelas eksperimen lebih tinggi dibandingkan data posttest hasil belajar matematika pada kelas kontrol. Adapun standar deviasi (simpangan baku), varians dan skewness pada kelas eksperimen berturut-turut adalah 24; 576,042 dan 0,015 sedangkan standar deviasi, varians dan skewness pada kelas kontrol berturut-turut adalah 24,04; 577,978 dan 0,803. Hal ini menunjukkan bahwa hasil belajar matematika siswa kelas eksperimen lebih beragam dibandingkan dengan hasil belajar matematika siswa kelas kontrol.

\begin{tabular}{|c|c|c|}
\hline $\begin{array}{c}t \\
\text { hitung }\end{array}$ & $\frac{\text { Sig(2-tailed })}{\mathbf{2}}$ & Keputusan \\
\hline 3,11 & 0,0015 & \\
\hline
\end{tabular}


Berdasarkan hasil analisis uji-t diperoleh $\mathrm{t}_{\text {hitung }}=3,11>\mathrm{t}_{\text {tabel }}=2,013$ atau nilai $\frac{\text { Sig }(2 \text {-tailed })}{2}=0,0015<0,05 ;$ maka $\mathrm{H}_{0}$ ditolak. Dengan ditolaknya $\mathrm{H}_{0}$, maka dapat disimpulkan bahwa terdapat pengaruh yang signifikan model pembelajaran kooperatif tipe Think Pair Share terhadap hasil belajar matematika siswa kelas VIII SMP Negeri 1 Pasarwajo pada pokok bahasan lingkaran dengan taraf kepercayaan $95 \%$.

\section{Pembahasan}

Salah satu faktor yang meyebabkan rendahnya hasil belajar siswa adalah penggunaan model pembelajaran yang kurang inovatif dan terlalu monoton. Model pembelajaran yang dapat membantu untuk meningkatkan hasil belajar siswa adalah model pembelajaran kooperatif tipe Think Pair Share. Untuk menjawab tujuan penelitian yang telah dikemukakan pada bab pertama, berikut adalah pembahasan tentang hasil belajar matematika siswa berdasarkan hasil penelitian yang telah diuraikan sebelumnya.

$$
\text { Selama proses pembelajaran }
$$

berlangsung, peneliti menggunakan dua kelas sampel penelitian yakni kelas yang diajar dengan model pembelajaran kooperatif tipe Think Pair Share sebagai kelas eksperimen dan kelas yang diajar dengan model pembelajaran langsung sebagai kelas kontrol. Kegiatan pembelajaran dengan model pembelajaran kooperatif tipe Think Pair Share di kelas eksperimen dimulai dengan tahap pendahuluan, yakni guru melakukan orientasi dengan membuka pembelajaran dan menyiapkan fisik dan psikis siswa untuk menerima pelajaran. Dilanjutkan dengan tahap apersepsi dan motivasi serta pemberian acuan kepada siswa untuk memberitahukan materi pembelajaran yang akan dibahas. Dilanjutkan dengan pembentukan kelompok siswa berpasangan secara heterogen. Pada kegiatan inti pembelajaran, masing-masing kelompok diberikan LKPD untuk diselesaikan secara berkelompok, namun sebelum itu siswa harus mengerjakannya secara mandiri lalu kemudian mendiskusikan jawaban yang diperoleh bersama pasangannya. Pada saat siswa menyelesaikan soal dalam LKPD, guru membimbing siswa secara individu maupun kelompok dengan cara mengarahkan kepada penyelesaian masalah. Setelah semua kelompok mengerjakan LKPD sesuai waktu yang telah ditentukan, siswa mengkomukasikan hasil kerja kelompoknya dan ditanggapi oleh kelompok lain. Guru mendorong siswa agar secara aktif terlibat dalam diskusi kelompok serta saling membantu dalam menyelesaikan soal/masalah yang diberikan. Setelah tahap diskusi kelompok selesai, siswa melatih kreativitasnya dengan menyimpulkan poin-poin penting dalam diskusi dengan menyiapkan laporan hasil pengamatan secara tertulis. Pada kegiatan penutup, guru bersama siswa melakukan refleksi dan evaluasi terhadap pembelajaran yang dilakukan dan memberikan tugas untuk dikerjakan dirumah secara individu.

$$
\text { Ditinjau dari aktifitas guru, }
$$
keterlaksanaan proses pembelajaran selama tujuh kali pertemuan sudah baik. Terjadi peningkatan dan penurunan keterlaksanaan proses pembelajaran pada setiap pertemuan. Persentase keberhasilan keterlaksanaan pembelajaran pada pertemuan pertama dan keempat lebih tinggi dibandingkan kelima pertemuan lainnya. Pada pertemuan pertama dan keempat, Karena siswa sangat antusias terhadap model pembelajaran Think Pair Share yang baru diterapkan, guru kesulitan dalam mengontrol semua siswa ketika menyelesaikan soal dalam LKPD. Masing masing kelompok membutuhkan guru untuk menanyakan hal-hal yang tidak dipahami dalam menyelesaikan soal yang ada pada LKPD. Sehingga membutuhkan waktu yg lama bagi guru untuk dapat mengontrol semua kelompok. Namun pada pertemuan kedua, ketiga, kelima, keenam dan ketujuh terjadi penurunan persentase aktivitas guru dalam kelas. Karena waktu yang diperlukan untuk mengontrol setiap kelompok dalam proses pembelajaran, pada pertemuan kedua dan seterusnya guru tidak lagi menjelaskan langkah-langkah pembelajaran kepada siswa. Guru merasa bahwa siswa telah memahami langkah-langkah pembelajaran yang telah dijelaskan pada pertemuan pertama. Hal ini juga dilakukan untuk menghemat waktu pelajaran agar guru lebih dapat mengontrol siswa dalam menyelesaikan tugas kelompok secara menyeluruh. Namun hal tersebut belum cukup untuk menghemat waktu pelajaran sehingga pada beberapa pertemuan, guru tidak dapat membimbing siswa menyimpulkan materi pelajaran pada pertemuan itu dan tidak dapat melakukan refleksi terhadap pembelajaran yang dilakukan secara menyeluruh dikarenakan jam pelajaran yang tidak mencukupi. Tetapi guru 
telah memastikan bahwa siswa dapat mengerti mengenai materi apa saja yang telah dibahas pada pertemuan itu. Hal tersebut dapat dilihat dari nilai yang diperoleh siswa di setiap kelompok dalam mengerjakan soal LKPD.

Selama tujuh kali pertemuan dengan menggunakan model pembelajaran kooperatif tipe Think Pair Share pada kelas eksperimen, tingkat keaktifan siswa dalam mengikuti pembelajaran sudah baik. Pada pertemuan pertama dan kedua, siswa secara aktif menyelesaikan permasalahan yang diberikan dalam LKPD bersama pasangannya. Namun, ketika presentasi dilakukan, mereka masih belum terlalu berani dan percaya diri untuk mengemukakan pendapatnya masing-masing. Dan juga mereka masih terkesan tidak dapat menerima apabila terdapat pendapat berbeda dari kelompok lain. Pada pertemuan ketiga, persentase keaktifan siswa dalam kelas mengalami penurunan, tidak seperti pada pertemuan sebelumnya, terdapat beberapa kelompok yang tidak membawa buku pelajaran sehingga menyebabkan mereka tidak dapat saling bekerja sama menggali dan mengolah informasi dari buku pelajaran untuk menyelesaikan soal dalam LKPD. Namun pada saat presentasi dilakukan, para siswa lebih percaya diri dalam mengemukakan hasil diskusi kelompoknya dan dapat menerima perbedaan pendapat dari kelompok lain.

Pada pertemuan keempat, persentase keaktifan siswa dalam pembelajaran di kelas kembali meningkat. Akan tetapi, masih ada beberapa siswa yang tidak memperhatikan ketika guru memberikan materi pelajaran serta kurangnya antusias siswa untuk bertanya kepada guru tentang hal-hal yang kurang dimengerti. Pada pertemuan kelima, tingkat keaktifan siswa menurun. Kekurangan yang terjadi pada pertemuan sebelumnya masih terulang kembali, beberapa siswa dalam kelompok tidak antusias ketika menggali dan mengolah informasi yang diperoleh dari buku pelajaran.

Pada pertemuan keenam, persentase keaktifan siswa dalam pembelajaran di kelas mengalami peningkatan dari pertemuan sebelumnya. Semua siswa melakukan aktifitas sesuai dengan tahap-tahap model pembelajaran kooperatif tipe Think Pair Share. Namun pada pertemuan terakhir, guru tidak lagi memberikan tugas rumah kepada siswa agar siswa lebih fokus belajar mempersiapkan diri untuk menghadapi soal posttest yang akan dilaksanakan pada pertemuan berikutnya.

Dari Penjelasan di atas mengenai deskripsi pembelajaran matematika pada kelas eksperimen dengan model pembelajaran kooperatif tipe Think Pair Share, apabila dibandingkan dengan model pembelajaran langsung maka model pembelajaran kooperatif tipe Think Pair Share lebih baik dalam meningkatkan keaktifan siswa dalam pembelajaran. Siswa dalam kelas kontrol dengan model pembelajaran langsung cenderung tidak aktif dan tidak ada rasa ingin tahu yang tinggi kepada pelajaran yang diberikan oleh guru. Hambatan yang sering terjadi ketika pembelajaran berlangsung adalah pengetahuan awal siswa yang sangat kurang, siswa tidak tertarik untuk memperhatikan penjelasan yang diberikan oleh guru dan hanya bermain dengan temannya. Rasa ingin tahu siswa menjadi berkurang karena guru lebih mendominasi ketika proses pembelajaran dalam kelas. Akibatnya, siswa menjadi kurang percaya diri ketika tampil di depan kelas untuk mempresentasikan hasil kerjanya. Dengan demikian, dari hasil penelitian yang telah dilakukan maka peneliti sangat menyarankan penggunaan model pembelajaran kooperatif tipe Think Pair Share untuk meningkatkan aktivitas siswa agar lebih mendominasi ketika proses pembelajaran di kelas sehingga siswa pun lebih tertarik untuk belajar.

Berdasarkan hasil analisis deskriptif dari data yang diperoleh melalui tes hasil belajar matematika siswa, pada posttest kelas eksperimen diperoleh nilai rata-rata yang lebih tinggi dibandingkan dengan nilai rata-rata kelas kontrol. Berdasarkan nilai rata-rata, maka hasil belajar matematika kelas eksperimen lebih tinggi dari hasil belajar matematika siswa kelas kontrol. Hal ini mengidentifikasikan bahwa dari indikator nilai rata-rata, model pembelajaran kooperatif tipe Think Pair Share mampu memberi pengaruh yang cukup baik dalam meningkatkan hasil belajar matematika siswa. Dari indikator keragaman data (varians), data posttest kelas eksperimen memiliki varians lebih besar dibandingkan varians data posttest kelas kontrol. Nilai varians dari kedua kelompok tersebut menunjukkan bahwa hasil belajar matematika siswa kelas eksperimen lebih beragam daripada kelas kontrol. Sedangkan dari indikator skewness, kelas eksperimen memiliki lebih banyak siswa dengan hasil belajar di atas 
rata-rata, sedangkan kelas kontrol memiliki lebih banyak siswa dengan hasil belajar di bawah ratarata. Berdasarkan indikator nilai maksimum, kelas kontrol memiliki nilai yang lebih tinggi daripada kelas eksperimen. Adapun berdasarkan indikator nilai minimum, modus dan median, data posttest hasil belajar siswa kelas eksperimen lebih tinggi daripada data posttest hasil belajar siswa pada kelas kontrol. Sehingga secara umum dapat dikatakan bahwa hasil belajar matematika siswa kelas eksperimen yang diajar dengan model pembelajaran kooperatif tipe Think Pair Share lebih baik daripada hasil belajar siswa kelas kontrol yang diajar dengan model pembelajaran langsung.

Ada beberapa hal yang menyebabkan nilai posttest kelas eksperimen lebih tinggi daripada kelas kontrol. pembelajaran pada kelas kontrol menggunakan model pembelajaran langsung dimana guru menjadi pusat utama dalam kelas. Model pembelajaran ini sudah terbiasa digunakan oleh guru untuk mengajar di dalam kelas sehingga siswa merasa bosan terhadap pembelajaran yang berlangsung. Selain itu, pada model pembelajaran langsung, siswa tidak dapat mengeksplor diri dengan berdiskusi mengenai jawaban soal yang diberikan dalam LKPD. Akibat dari siswa merasa bosan terhadap pembelajaran yang dilakukan adalah siswa tidak dapat memahami penjelasan yang telah diberikan oleh guru, sehingga nilai siswa pun menjadi rendah. Namun apabila dibandingkan dengan nilai awal yang diperoleh peneliti, nilai ulangan harian yang diperoleh siswa kelas kontrol pada materi pola bilangan lebih tinggi dibandingkan hasil posttest yang diperoleh siswa pada materi lingkaran. Hal ini karena tingkat kesulitan soal posttest hasil belajar matematika lebih tinggi dibandingkan dengan soal ulangan harian siswa. Selain itu, kemampuan dan minat siswa terhadap materi yang diberikan dapat pula mempengaruhi nilai yang diperoleh. Namun berbeda dengan kelas eksperimen, nilai yang diperoleh siswa pada materi Lingkaran lebih tinggi dibandingkan nilai ulangan harian siswa pada materi pola bilangan. Ini karena kemampuan dan minat siswa pada kelas eksperimen relatif sama pada kedua materi tersebut.

Pada kelas eksperimen, siswa lebih antusias dalam menerima pelajaran yang diberikan oleh guru. Karena model pembelajaran yang digunakan merupakan model pembelajaran yang masih baru bagi siswa sehingga siswa lebih semangat dalam menerima pelajaran. Dengan menggunakan model pembelajaran kooperatif tipe Think Pair Share siswa dituntut agar lebih aktif dalam kelas, mendiskusikan jawaban bersama pasangannya (kelompok). Dengan jumlah anggota tiap kelompok sebanyak 2 orang, menyebabkan semua siswa aktif dan bersungguh-sungguh menjawab soal yang diberikan dalam LKPD. Akibatnya, siswa lebih memahami materi yang diberikan oleh guru. Hal-hal itulah yang menyebabkan mengapa hasil belajar matematika siswa kelas eksperimen yang diajar dengan model pembelajaran kooperatif tipe Think Pair Share lebih baik dari siswa kelas kontrol yang diajar dengan model pembelajaran langsung.

Penolakan $\mathrm{H}_{0}$ pada pengujian hipotesis dengan menggunakan uji-t (Independent Sample t-test) menunjukkan bahwa terdapat pengaruh yang signifikan model pembelajaran kooperatif tipe Think Pair Share terhadap hasil belajar matematika siswa kelas VIII SMP Negeri 1 Pasarwajo. Model pembelajaran kooperatif tipe Think Pair Share ini mendorong siswa untuk aktif secara individu maupun kelompok dalam pembelajaran untuk memecahkan masalah yang diberikan serta dapat menyimpulkan point-point penting yang menjadi pokok pembelajaran. Sehingga dari penelitian yang telah dilakukan, model pembelajaran kooperatif tipe Think Pair Share ini dapat dijadikan sebagai salah satu pertimbangan bagi guru untuk dapat diterapkan sebagai alternatif untuk meningkatkan hasil belajar siswa.

\section{Simpulan dan Saran}

\section{Simpulan}

Berdasarkan hasil penelitian dan pembahasan dalam penelitian ini, maka dapat dikemukakan beberapa kesimpulan sebagai berikut:

1. Proses pembelajaran dengan menggunakan model pembelajaran kooperatif tipe Think Pair Share pada kelas VIII SMP Negeri 1 Pasarwajo sangat baik. Secara keseluruhan persentase tingkat keterlaksanaan pembelajaran oleh guru pada 7 kali pertemuan adalah 99\%, $95 \%, 98 \%, 99 \%, 98 \%, 95 \%$ dan $94 \%$. Sedangkan persentase keaktifan siswa pada 7 kali pertemuan berturut-turut adalah $97 \%, 97 \%, 96 \%, 97 \%, 95 \%, 100 \%$ dan $98 \%$. 
2. Deskripsi hasil belajar matematika siswa kelas VIII SMP Negeri 1 Pasarwajo yang diajar dengan model pembelajaran kooperatif tipe Think Pair Share pada pokok bahasan lingkaran diperoleh nilai rata-rata 60,41 ; standar deviasi 24 ; varians 576,042; skewness 0,015 ; median 60; modus 26,25 ; nilai minimum 26,25 ; dan nilai maksimum 95.

3. Deskripsi hasil belajar matematika siswa kelas VIII SMP Negeri 1 Pasarwajo yang diajar dengan model pembelajaran langsung pada pokok bahasan lingkaran diperoleh nilai rata-rata 38,85 ; standar deviasi 24,04 ; varians 577,987 ; skewness 0,803 ; median 29,37; modus 20; nilai minimum 5; dan nilai maksimum 96,25.

4. Berdasarkan hasil analisis deskriptif dan inferensial, menunjukkan bahwa hasil belajar matematika siswa yang diajar dengan model pembelajaran kooperatif tipe Think Pair Share lebih tinggi daripada hasil belajar matematika siswa yang diajar dengan model pembelajaran langsung. Sehingga dapat dikatakan bahwa terdapat pengaruh yang signifikan penggunaan model pembelajaran kooperatif tipe Think Pair Share terhadap hasil belajar matematika siswa kelas VIII SMP Negeri 1 Pasarwajo.

\section{Saran}

Dari hasil penelitian ini dapat disarankan beberapa hal sebagai berikut:

1. Kepada guru yang mengajar mata pelajaran matematika sekiranya dapat menggunakan model pembelajar kooperatif tipe Think Pair Share dalam pembelajaran matematika di kelas untuk mengoptimalkan hasil belajar matematika siswa.

2. Seorang guru harus dapat memperhatikan keadaan siswa dalam menerapkan model pembelajaran kooperatif tipe Think Pair Share, Karena tidak semua siswa dapat dengan mudah menyesuaikan diri dengan langkah-langkah pembelajaran dalam model pembelajaran tersebut. Selain itu, pembagian kelompok oleh guru harus dilakukan secara heterogen agar dapat terjalin kerjasama yang baik antar siswa dalam kelompok.

3. Bagi peneliti yang hendak mengembangkan penelitian ini dapat melakukannya pada pokok bahasan lain dengan memperhatikan alokasi waktu pembelajaran sehingga proses pembelajaran dengan model pembelajaran kooperatif tipe Think Pair Share bisa berjalan lebih optimal.

\section{Daftar Pustaka}

Ahiri, Jafar. \& Anwar Hafid. (2011). Evaluasi Pembelajaran Dalam Konteks KTSP. Bandung: Humaniora.

Arikunto, Suharsimi. (2015). Dasar-Dasar Evaluasi Pendidikan. Jakarta: Bumi Aksara.

Daryanto. (2013). Inovasi Pembelajaran Efektif. Bandung: Yrama Widya.

Hamzah, Ali dan Muhlisrarini. (2014). Perencanaan dan Strategi Pembelajaran Matematika. Jakarta: PT Rajagrafindo Persada.

Jihad, Asep dan Abdul Haris. (2008). Evaluasi Pembelajaran. Yogyakarta: Multi Pressindo

Kurniasih, Imas. dan Berlin Sani. (2017). Ragam Pengembangan Model Pembelajaran. Yogyakarta: Kata Pena.

Rosa, Yuvita Erpina, dkk. (2015). Metode Scheffe Dalam Uji Komparasi Ganda Analisis Dua Faktor Dengan Interaksi. Buletin Ilmiah Matf. Stat. Dan Terapannya (Bimaster).. Vol 04, No.3, 2015, hal: 375

Sarwadi. (2015). Big Drilling Soal + Pembahasan Tes Potensi Akademi (TPA). Yogyakarta: Pustaka Baru Press.

Shoimin, Aris. (2014). 68 Model Pembelajaran Inovatif Dalam Kurikulum 2013. Yogyakarta: Ar-Ruzz Media.

Sugiyono. (2016). Metode Penelitian Kombinasi (Moxed Methods). Bandung: CV Alfabeta.

Supardi.(2017). Statistik Penelitiam Pendidikan: Perhitungan, Penyajian, Penjelasan, Penafsiran, dan Penarikan Kesimpulan. Depok: Rajawali Pers. 
Suprihatiningrum, Jamis. (2013). Strategi Pembelajaran: Teori \& Aplikasi. Yogjakarta: Ar-Ruzz Media.

Trianto, (2007). Model-Model Pembelajaran Inovatif Berorientasi Kontruktivistik. Jakarta, Prestasi Pustaka.
Wena, Made. (2010). Strategi Pembelajaran Inovatif Kontemporer Suatu Tinjauan Konseptual Operasional. Jakarta: Bumi Aksara 